\title{
Contact with a solid substratum induces cysts in axenic cultures of Physarum polycephalum amoebae: mannitol-induced detergent- resistant cells are not true cysts
}

\author{
Jennifer Dee, ${ }^{1}$ Jennifer L. Foxon, ${ }^{1}$ Wendy Hill, ${ }^{2}$ Evaline M. Roberts ${ }^{2}$ \\ and Muriel $\mathrm{H}$. Walker ${ }^{2}$ \\ Author for correspondence: Jennifer Dee. Tel: +44 116252 3426. Fax: +44 1162523378. \\ e-mail: jjd2@le.ac.uk
}

1 Department of Genetics, University of Leicester, Leicester LE1 7RH, UK

2 Department of Zoology, University of Leicester, Leicester LE1 7RH, UK

\begin{abstract}
Previous workers reported that Physarum polycephalum amoebae cultured in liquid axenic medium were induced to form cysts by the addition of mannitol. Their criterion for encystment was the formation of detergent (Triton)resistant cells (TRC). In this study the frequencies of TRC in suspensions of amoebae from various treatments were compared with counts of cell types identified by transmission electron microscopy. Amoebae treated with mannitol in axenic liquid culture formed $50 \%$ TRC after $17 \mathrm{~h}$ but no walled cysts were found. It was concluded that TRC induced by mannitol were dense, rounded cells without walls. In contrast, TRC formed after growth to stationary phase on bacterial lawns were walled cells. When resuspended in growth medium, most mannitol-induced TRC reverted to active amoebae within a few minutes, whereas TRC formed on bacteria remained Triton resistant for many hours. It was concluded that delayed reversion of TRC was a more reliable indication of wall formation than Triton resistance alone. Transfer of amoebae from liquid culture to the surface of diluted axenic agar medium resulted in the formation of walled cysts identical in appearance with those formed on bacterial lawns. The results indicated that efficient encystment requires a solid substratum as well as nutrient deprivation.
\end{abstract}

Keywords: Physarum, encystment, ultrastructure, mannitol, myxomycete

\section{INTRODUCTION}

In free-living amoebae of the slime mould Physarum polycephalum, encystment is a reversible cellular transformation which occurs in conditions unfavourable for growth, such as food deprivation, cold or drought. An encysted amoeba is surrounded by a wall, composed mainly of polysaccharide (Henney \& Chu, 1977), which allows it to survive adverse conditions and disperse to more favourable sites (Madelin, 1990). Excystment to release an active amoeba occurs readily in the presence of water or a fresh food supply (Howard, 1931; Raub \& Aldrich, 1982).

For classical genetic analysis and mutant isolation, $P$. polycephalum amoebae are cultured on lawns of bac-

Abbreviations: TRC, Triton-resistant cell; SDM, semi-defined medium; FKB, formalin-killed bacteria; DSDM, dilute semi-defined medium; LM, light microscopy; TEM, transmission electron microscopy. teria. In these conditions, encystment occurs soon after the food supply is exhausted. Cysts are valuable for the storage of genetically defined strains since they survive long periods at $4{ }^{\circ} \mathrm{C}$, frozen at $-80^{\circ} \mathrm{C}$, or desiccated on silica gel (Anderson et al., 1983). Strains of amoebae able to grow in liquid axenic medium (Axe strains; Dee $e$ t al., 1989) are essential for molecular genetic analyses, including DNA transformation (Burland et al., 1993). Stationary-phase cultures in liquid medium yield cysts at only very low frequencies, however. To facilitate biochemical studies of the process, several authors have attempted to induce encystment in axenic cultures. Earlier studies of $P$. polycephalum plasmodial cultures in liquid medium (Chet $\&$ Rusch, 1969), had shown that mannitol induced the formation of spherules (sclerotia), a process considered analogous to amoebal encystment. Turner \& Johnson (1975a, b, c) reported biochemical and ultrastructural changes indicative of encystment, but the changes they observed were slow and asynchronous. 
Cyst walls are not visible by phase-contrast microscopy and refractility is an unreliable indicator of cyst formation (Gorman et al., 1977; Haars et al., 1979). Gorman et al. (1977) showed that cysts formed on bacterial lawns could be distinguished from amoebae by their resistance to the stain trypan blue after treatment with the detergent Triton X-100. Amoebae were either lysed or stained blue by such treatment, while cysts remained unstained and viable. The presence of a wall on the detergent-resistant cells formed on bacteria was confirmed by electron microscopy.

Detergent resistance was used by Haars et al. (1979) to compare the effects of a range of carbohydrates on encystment in liquid, axenic cultures of $P$. polycephalum amoebae. A medium containing $0.5 \mathrm{M}$ mannitol was the most effective, inducing $45-50 \%$ detergent-resistant cells after $24 \mathrm{~h}$. Ultrastructural examination indicated that these cells did not possess walls, however, and they reverted to amoebae within $30 \mathrm{~min}$ of transfer to fresh growth medium (Haars et al., 1979). In contrast, cysts formed on bacteria required many hours for reversion in growth medium (Gorman et al., 1977). Binette et al. (1988) reported that encystment of $P$. polycephalum amoebae was induced in liquid cultures by prolonged incubation in the presence of glucose, but apparently relied entirely on detergent resistance to detect cysts.

Since ultrastructural examination gives the only reliable indication of cyst wall formation, we have correlated the frequencies of cell types seen in transmission electron microscopy (TEM) sections with the frequencies of detergent-resistant cells in suspensions subjected to different treatments. Since there was no evidence from previous studies, or from our own work, that significant frequencies of walled cysts could be induced by mannitol or glucose, we explored other methods of inducing encystment in axenic conditions. We used quantitative ultrastructural studies in addition to tests of detergent resistance to assess the effectiveness of different treatments.

\section{METHODS}

Strains. LU352, an Axe strain of $P$. polycephalum amoebae able to grow in axenic medium, was used for all experiments (for detailed description and origin, see Dee et al., 1989).

Media and chemicals. Sterilization was by autoclaving except where otherwise stated. SDM (semi-defined medium) contained $10.0 \mathrm{~g}$ glucose, $10.0 \mathrm{~g}$ Soytone (Difco-Bacto), $2.0 \mathrm{~g}$ $\mathrm{KH}_{2} \mathrm{PO}_{4}, 0.9 \mathrm{~g} \mathrm{CaCl}_{2} .6 \mathrm{H}_{2} \mathrm{O}, 0.6 \mathrm{~g} \mathrm{MgSO}_{4} .7 \mathrm{H}_{2} \mathrm{O}, 2 \times 10^{-8} \mathrm{M}$ $\mathrm{FeCl}_{2} \cdot 4 \mathrm{H}_{2} \mathrm{O}, 0.034 \mathrm{~g} \mathrm{ZnSO} .7 \mathrm{H}_{2} \mathrm{O}, 3.54 \mathrm{~g}$ citric acid, $0.005 \mathrm{~g}$ biotin, $0.04 \mathrm{~g}$ thiamin, $\mathrm{H}_{2} \mathrm{O}$ to 1 litre; the $\mathrm{pH}$ was adjusted to 4.6 with $20 \% \mathrm{NaOH}$. Haematin stock solution $(0.5 \mathrm{~g}$ Sigma bovine haematin or haemin chloride, $10 \mathrm{~g} \mathrm{NaOH}, \mathrm{H}_{2} \mathrm{O}$ to 1 litre; stored at $\left.4{ }^{\circ} \mathrm{C}\right)$ was added immediately before use $(10 \mathrm{ml}$ $\left.1^{-1}\right)$. To prepare SDM agar, molten $3 \%(\mathrm{w} / \mathrm{v})$ agar was mixed with an equal volume of SDM (containing haematin) just before use. DSDM agar (dilute SDM agar) consisted of $62.5 \mathrm{ml}$ SDM (containing haematin) and 1 litre $1.5 \%(\mathrm{w} / \mathrm{v}$ ) agar (final $\mathrm{pH} 4 \cdot 6$ ). DSPB agar (dilute SDM agar with phosphate buffer) consisted of $62.5 \mathrm{ml} \mathrm{SDM}$ (containing haematin), $10 \mathrm{ml} 1 \mathrm{M}$ sodium phosphate buffer ( $\mathrm{pH} \mathrm{6.8)}$ ) and 1 litre $1.5 \%(\mathrm{w} / \mathrm{v})$ agar (final $\mathrm{pH}$ 6.8). FKB (formalin-killed bacteria-Escherichia coli) were prepared as described by Dee (1986) but resuspended in basal salts solution (Bailey et al., 1994) instead of water. Mannitol medium contained $1 \mathrm{M}$ mannitol solution (filter-sterilized) mixed with an equal volume of SDM (containing haematin) just before use.

\section{Culture methods}

All cultures were incubated at $30^{\circ} \mathrm{C}$ unless specified otherwise to avoid the possibility of apogamic plasmodium formation, which occurs at low frequency when LU352 amoebae are incubated at lower temperatures (Dee et al., 1989).

Cultures of amoebae in liquid axenic medium. These were maintained in SDM as described by Dee et al. (1989). Subcultures were made approximately twice per week and the cells were kept in exponential growth by subculturing before the density reached $2 \times 10^{7}$ cells $\mathrm{ml}^{-1}$. Approximately 4-5 cell doublings occurred between subcultures. The 'sub' number defines the number of subcultures since the amoebae were inoculated in liquid medium from a culture on bacteria; this information is recorded because cellular properties change during repeated subculturing in liquid medium (Dee et al., 1989, and unpublished results). Cultures are re-initiated at intervals of a few months from frozen stocks of amoebae cultured on bacteria (Dee, 1986; Dee et al., 1989).

Mannitol treatment of liquid cultures. Amoebae cultured in SDM were spun down and resuspended in an appropriate volume of mannitol medium, dispensed in culture tubes and incubated on a shaker at $30^{\circ} \mathrm{C}$, as for liquid cultures (Dee et al., 1989). Several tubes were sampled and Triton-tested at each timepoint.

Cultures of amoebae on agar media. Plates were inoculated with suspensions of amoebae from liquid cultures. For experiments on bacterial lawns, $100 \mu \mathrm{l} \mathrm{FKB}$ was added to each plate. The amoebal and bacterial suspensions were spread together over an area of $5 \mathrm{~cm} \times 5 \mathrm{~cm}$, using a bent glass rod. The total volume of inoculum on each plate was not more than $200 \mu \mathrm{l}$. For experiments on axenic agar, each plate was inoculated with $200 \mu \mathrm{l}$ amoebal suspension from a culture approaching stationary phase, and spread as above without bacteria. To assay the cultures, $2 \mathrm{ml} \mathrm{SDM}$ was added to each plate and the cells were harvested after they had been detached from the agar by rubbing the surface with a glass spreader. Cell number per plate was calculated as $2 \times$ (cell number $\mathrm{ml}^{-1}$ in the harvested suspension), estimated in a haemacytometer. At least two plates were assayed at each time-point.

Cell counts. A phase-contrast microscope and haemacytometer with Thoma ruling was used. The lowest cell density detectable was approximately $10^{4}$ cells $\mathrm{ml}^{-1}$. For the purpose of statistical tests, the actual numbers of cells counted were compared with the counts made on thick sections of the pellets prepared for transmission electron microscopy (TEM).

Triton test. To each $200 \mu \mathrm{l}$ sample of cell suspension, $2 \mu \mathrm{l}$ $2.5 \%(\mathrm{v} / \mathrm{v})$ Triton $\mathrm{X}-100$ in water was added and the suspension mixed by vortexing for $10 \mathrm{~s} ; 10 \mu \mathrm{l} 0.4 \%(\mathrm{w} / \mathrm{v})$ trypan blue (Sigma) was added and mixed ( $3 \mathrm{~s}$ ), and after $5 \mathrm{~min}$, samples were examined in a haemacytometer. Unstained cells were defined as TRC (Triton-resistant cells); this definition refers to resistance to staining by trypan blue, and does not necessarily imply viability. Total cell counts were made on samples of suspension before Triton treatment, as well as on the Triton-treated samples; if similar total counts were obtained, the total count from the Triton test alone was used for the calculation of the percentage of Triton-resistant cells (\% TRC). 
Electron microscopy. Cell suspensions were prepared for TEM as described in Results, the cell density being adjusted to between $1 \times 10^{6}$ and $5 \times 10^{6} \mathrm{ml}^{-1}$ before fixation. To fix cells, glutaraldehyde (AGAR Scientific) was added to the suspensions to a final concentration of $2.5 \%$. The tubes were inverted to mix and the cells left to fix for $1 \mathrm{~h}$ prior to washing three times in $0.067 \mathrm{M}$ phosphate buffer, $\mathrm{pH} 7 \cdot 2$. Cells were resuspended in $500 \mu \mathrm{l}$ buffer in microcentrifuge tubes and were fixed for a further $90 \mathrm{~min}$ by adding $500 \mu \mathrm{l} 2 \% \mathrm{OsO}_{4}$ (AGAR Scientific) to each tube. Fixed cells were then washed four times in distilled water, pelleted in $2 \%$ molten agar and cooled rapidly on ice. Agar pellets were divided into upper and lower regions so that any differential centrifugation of TRC and amoebae during preparation would be detected. After division, pieces of the agar pellet were dehydrated through an ethanol series and placed in several changes of propylene oxide prior to infiltration with Spurr low-viscosity embedding medium. Specimens were infiltrated in a 3:1 propylene oxide/Spurr mixture for $5 \mathrm{~h}$, then in a 50:50 mixture overnight. After several hours in $100 \%$ Spurr, samples were embedded in fresh $100 \%$ Spurr.

Thick sections $(0.5 \mu \mathrm{m})$ were cut with glass knives on a Tesla ultramicrotome, mounted on glass slides, stained with $1 \%$ Toluidine blue (Sigma) in $1 \%$ borax, and observed and photographed using an Olympus BHS photomicroscope. Thick sections were used to locate areas with good cell density for thin sections. Photographs of thick sections were used to count the different cell types in each preparation. Thin sections were cut from each block with a diamond knife using a Reichert ultramicrotome, stained with filtered, saturated uranyl acetate (AGAR Scientific) and lead citrate, and examined using a Siemens 100 s transmission electron microscope.

\section{RESULTS AND DISCUSSION}

\section{Cultures on lawns of formalin-killed bacteria (FKB)}

To investigate whether the Axe strain LU352 formed normal cysts when cultured on bacteria, various media were inoculated with amoebae from liquid cultures in the exponential phase and incubated until the cultures reached stationary phase. Samples were harvested at intervals in SDM to assay cell number and \% TRC. Efficient and repeatable formation of TRC was obtained on lawns of FKB on DSPB agar. Cell number initially increased exponentially, reaching stationary phase after $3 \mathrm{~d}$ incubation. TRC were first detected at day $2(4.8 \%$ TRC) and $88 \%$ TRC were present by day 4 . Samples were prepared for TEM analysis from the cell suspensions harvested at days 1 and 4 . For comparison, preparations were also made of LU352 amoebae harvested in SDM during exponential growth in liquid culture (sub 22). All samples were fixed by addition of glutaraldehyde to cell suspensions in SDM.

TEM observations. Amoebae from liquid cultures (Fig. 1a) were characterized by the presence of pseudopodia and numerous apparently empty vacuoles in cytoplasm of moderate electron density. Also visible in these cells were mitochondria with tubular cristae, rough endoplasmic reticulum and nuclei with a layer of heterochromatin around the periphery, clumps of heterochromatin, and a conspicuous nucleolus organizer. In cultures harvested after $1 \mathrm{~d}$ on DSPB with FKB, the amoebae were similar in most respects to amoebae from liquid cultures, but numerous vacuoles were present, the larger of which contained a variety of inclusions indicating their role in digestion (Figs 1b,c). In the pseudopodial regions of the cells (Fig. 1b), all types of organelle were excluded and microfilaments were observed at higher magnifications.

In cultures harvested after $4 \mathrm{~d}$ on DSPB with FKB (Fig. $1 \mathrm{~d})$, walled cells and dying cells were visible, in addition to amoebae similar to those seen in the 1-day cultures. The walled cells were predominantly spherical (Fig. 1e) with a fibrillar cell wall, approximately $12-14 \mathrm{~nm}$ thick, which in some instances appeared to be multilayered (Fig. 1f). The wall was separated from the cell surface by a distance of between $0 \cdot 15-0 \cdot 35 \mu \mathrm{m}$ (Figs $1 \mathrm{e}, \mathrm{g}$ ). The nuclei of the walled cells contained clumped heterochromatin and a nucleolus organizer (Figs 1e, g). In the cytoplasm of the walled cells, one or two large vacuoles were sometimes visible; numerous smooth membrane vesicles with fibrous content, mitochondria and electron-dense spherical granules with ribosomes clustered around them were also present (Fig. 1e, g). The surfaces of these cells were crenate (Fig. 1g). In some walled cells, the space between the wall and the cell contained accumulations of material similar to the cell wall (Fig. $1 \mathrm{~g}$ ). Some cells intermediate in appearance between amoebae and walled cells were also seen in cultures harvested after $4 \mathrm{~d}$; these cells had no walls but contained some of the electron-dense granules seen in the walled cells and not observed in amoebae. The cytoplasm of these cells contained a few large vacuoles, some of which could be digestive in function, and rough endoplasmic reticulum, some of it located beneath the cell membrane. They also contained smooth membrane vesicles, some of which appeared to fuse with the cell membrane, where material was in process of extrusion from the cell surface (Fig. 1h).

The ultrastructural changes described above were similar to those observed during encystment of $P$. polycephalum amoebae by Aldrich \& Blackwell (1976) and Raub \& Aldrich (1982). The electron-dense granules seen were similar to those described in starving plasmodia and spherules in Didymium and P. polycephalum (Rhea, 1966), where they were often found near membranes of food vacuoles. Rhea (1966) suggested that their function may be to provide nucleic-acid-containing particles or to act as glycogen reserve granules. The cyst wall seen in our preparations was identical to that described by Raub \& Aldrich (1982) although the slime layer described by them was absent, possibly due to our preparation procedure. The results indicated that the Axe strain LU352 was capable of normal encystment when cultured on a lawn of FKB, and did not support previous suggestions that live bacteria might be necessary for normal encystment (Dee et al., 1989).

Correlation of walled cells with TRC formed on FKB. When thick sections of the day 4 preparations were examined by light microscopy (LM; Fig. 1d), it was possible to 


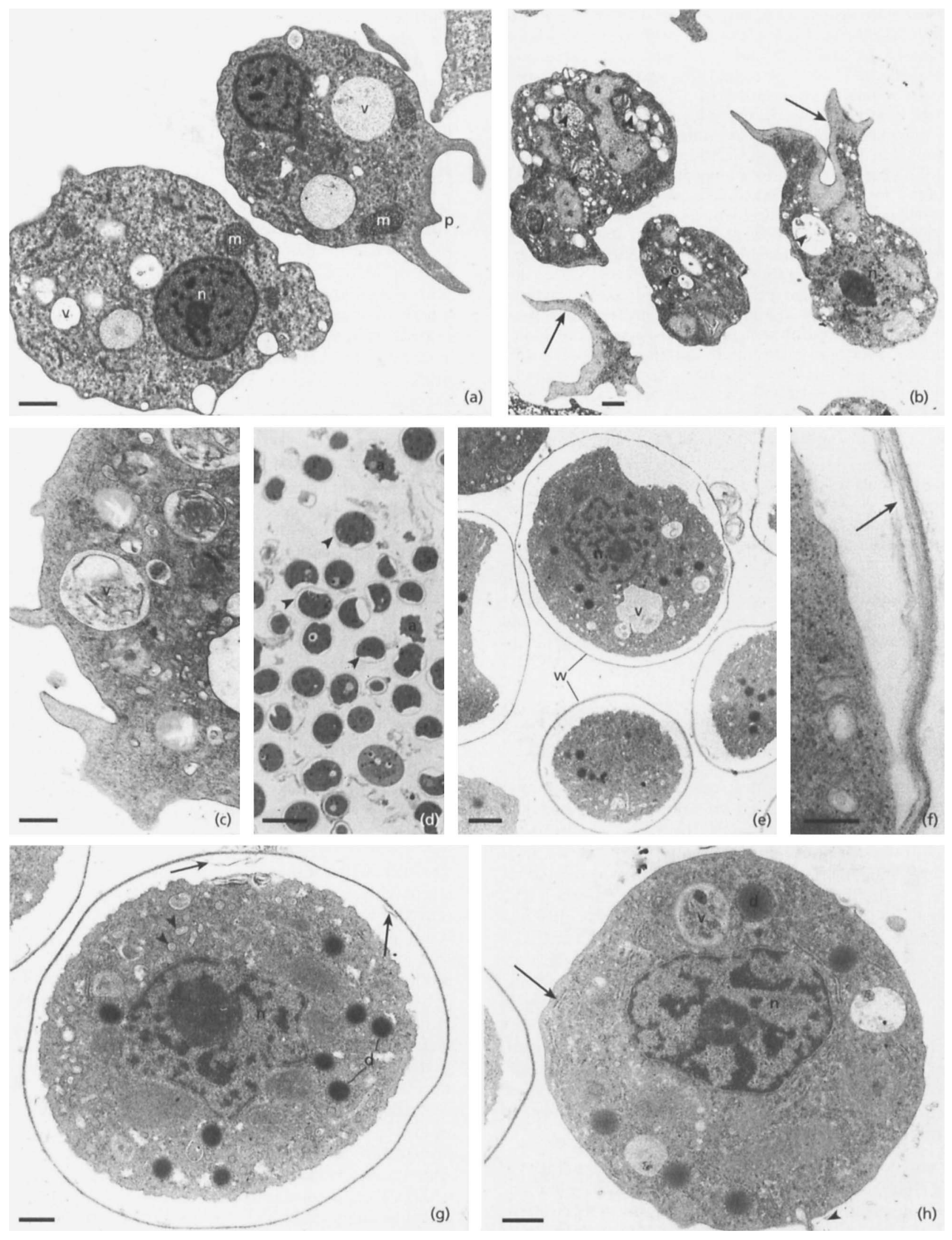

Fig. 1. For legend see facing page. 
Table 1. Cell types in populations cultured on lawns of FKB and harvested after $4 \mathrm{~d}$ incubation

\begin{tabular}{|llllll|}
\hline \multicolumn{5}{c}{ Cell types seen in LM counts of thick sections: } & \\
\cline { 2 - 5 } & Walled $(\boldsymbol{a})$ & Round $(\boldsymbol{b})$ & Amoeboid $(\boldsymbol{c})$ & Dying $(\boldsymbol{d})$ & Total \\
\hline Lower pellet* & 169 & 40 & 8 & 7 & 224 \\
Upper pellet* & 208 & 58 & 10 & 18 & 294 \\
Total $\dagger$ & $377(72 \cdot 8 \%)$ & $98(18.9 \%)$ & $18(3.5 \%)$ & $25(4.8 \%)$ & 518 \\
\hline
\end{tabular}

* Counts for $(a)-(d)$ not significantly different between lower and upper pellets $\left(\chi^{2}=3 \cdot 0 ; n=3 ; P>\right.$ $0 \cdot 05)$.

†In the total cell counts, the ratio of $(a+b):(c+d)(475: 43)$ was not significantly different from the ratio of unstained cells : stained cells $(96: 13)$ in Triton tests prior to fixation $\left(\chi^{2}=1.5 ; n=1 ; P>0.05\right)$. The ratio of $a:(b+c+d)(377: 141)$ differed significantly from the ratio in the Triton tests $\left(\chi^{2}=11 \cdot 4\right.$; $n=1 ; P<0.001)$.

distinguish the amoeboid and walled cell types observed by TEM. In addition, some cells of intermediate appearance were seen; these were more rounded and had denser cytoplasm than amoebae but apparently no cell wall. A few cells which appeared to be dead or dying were also present. In thick sections of day 1 preparations, all cells were clearly classified as amoeboid (465) or dying (17) cells and no walled cells were seen.

To investigate whether the different cell types present in the 4-day samples were uniformly distributed in the pellet, counts were made on photographs of thick sections from lower and upper pellets (Table 1). This precaution was taken because our previous studies (unpublished) had suggested that cysts and amoebae differed in density and separated during centrifugation in Percoll gradients. No significant difference was found between the relative numbers of cell types in the two pellet sections; thus there was no evidence of differential settling of cysts and amoebae during preparation of samples for TEM.

Counts on upper and lower pellets were pooled to compare the frequency of the four cell types with the $\%$ TRC in the fixed sample. The percentage of walled cells in the pooled results $(72.8 \%)$ was lower than the $88.8 \%$ TRC detected in the Triton tests, and a statistical test indicated that the difference was significant (Table 1). Closer agreement was observed when the number of dense, rounded cells was added to the number of walled cells; the count was then not significantly different from the number of unstained cells in the Triton test. The results suggested that the majority of TRC formed by amoebae cultured on FKB were walled cysts but that the dense, rounded cells might also be Triton resistant.

\section{Mannitol induction of TRC formation in liquid cultures}

No TRC were detected in liquid cultures of amoebae in exponential growth. When Triton tests were applied to cultures which had reached a plateau at $4 \times 10^{7}$ cells $\mathrm{ml}^{-1}$, most cells lysed and only unstained cells were visible $\left(6 \times 10^{5}\right.$ cells $\left.\mathrm{ml}^{-1}\right)$. It was concluded that the stationary-phase cultures contained approximately $1.5 \%$ TRC.

Using a method similar to that of Haars et al. (1979), amoebae from cultures in exponential growth were induced to form TRC by resuspension in $0.5 \mathrm{M}$ mannitol medium. In repeat experiments, the percentage of TRC obtained after $24 \mathrm{~h}$ incubation in mannitol medium varied between $10 \%$ and $50 \%$. The number of TRC obtained was not increased by longer incubation or by harvesting the cells after $24 \mathrm{~h}$ and resuspending them in fresh mannitol medium. Although the apparent \% TRC sometimes increased after longer incubation, this was associated with a decrease in total cell number, probably due to cell death and lysis.

To investigate possible factors affecting \% TRC, amoebae were harvested from cultures at different stages of growth and resuspended in mannitol medium at different cell densities. Within each experiment, all samples gave similar \% TRC; there was no evidence that $\%$ TRC was affected by cell density either in the SDM

Fig. 1. P. polycephalum amoebae, walled and non-walled cells. TEM micrographs unless stated otherwise (d, electrondense granules; $m$, mitochondria; $n$, nucleus; $p$, pseudopodia; $v$, vacuoles; $w$, wall). (a) Amoebae from liquid culture, fixed in SDM. Bar, $1 \mu \mathrm{m}$. (b) Amoebae $1 \mathrm{~d}$ after transfer from liquid culture to DSPB with FKB. All types of organelles are excluded from pseudopodial regions (arrows) of these cells (arrowheads indicate vacuoles). Bar, $1 \mu \mathrm{m}$. (c) Part of an amoeba after $1 \mathrm{~d}$ on DSPB with FKB. Bar, $0.5 \mu \mathrm{m}$. (d) Light micrograph showing amoebae (labelled 'a') and walled cells (arrowheads) in cultures harvested after $4 \mathrm{~d}$ on DSPB with FKB. Bar, $10 \mu \mathrm{m}$. (e) A group of walled cells harvested after $4 \mathrm{~d}$ on DSPB with FKB. Bar, $1 \mu \mathrm{m}$. (f) Multilayered wall (arrow) of a cell harvested after $4 \mathrm{~d}$ on DSPB with FKB. Bar, $0.25 \mu \mathrm{m}$. (g) A walled cell formed on DSPB with FKB with a crenulated surface. Material comparable to the cell wall is seen in the space between the cell and the wall (arrows) (arrowheads indicate smooth membrane vesicles). Bar, $0.5 \mu \mathrm{m}$. (h) A nonwalled cell harvested after $4 \mathrm{~d}$ on DSPB with FKB. There is much rough endoplasmic reticulum, some of it beneath the cell membrane. Some smooth membrane vesicles appear to fuse with the cell membrane (arrowhead). Bar, $0.5 \mu \mathrm{m}$. 
cultures or in the mannitol medium. Our results did not support the suggestion by Williams \& Lafontaine (1984) that amoebae at different growth stages responded differently to mannitol.

To establish the kinetics of TRC formation, replicate cultures in mannitol medium were sampled at intervals for total cell counts and Triton tests. The results of two experiments with LU352 amoebae (subs 8 and 11 respectively) are shown in Fig. 2. In both experiments, a high proportion of rounded, refractile cells were formed immediately after resuspension in mannitol medium, but few TRC were detectable until $7 \mathrm{~h}$ after the start of mannitol treatment. The rise in TRC was then rapid and a plateau was reached before $15 \mathrm{~h}$. The total cell number remained constant during this time. The $\%$ TRC at the plateau was about $30 \%$ in experiment 1 and $18 \%$ in experiment 2 .

Viability of mannitol-induced TRC after Triton treatment. Amoebae that had been in mannitol medium for $20 \mathrm{~h}$ were treated with Triton and trypan blue, washed and resuspended in SDM. During subsequent incubation, the dead, stained cells gradually clumped and adhered to the culture tubes, while counts of the unstained cells showed a doubling time nearly as short as that of the cultures used to set up the experiment. The results indicated that the majority of mannitol-induced TRC survived Triton treatment in the presence of mannitol and reverted rapidly to an active state in SDM. No growth was observed in cultures that had been Tritontreated in SDM.

Ultrastructural examination. LU352 amoebae (sub 19) were resuspended in mannitol medium at a total cell density of $4 \cdot 8 \times 10^{6}$ per ml. After $17 \mathrm{~h}$ incubation, there was no decrease in total cell number, and Triton tests showed $52 \cdot 1 \%$ TRC. The suspension was then divided for TEM examination; one sample was fixed in mannitol medium and the other in mannitol medium supplemented with Triton (final concentration $0.025 \%$ ) to facilitate the identification of TRC.

In the sample fixed in mannitol medium, two distinct cell types were present : highly vacuolated amoebae with distinct pseudopodia; and rounded, dense cells that lacked clear vacuoles. The nuclei of the vacuolated amoebae had a conspicuous nucleolus organizer and the cytoplasm contained mitochondria, rough endoplasmic reticulum and large vacuoles (Fig. 3a). The cytoplasm of the rounded cells was more electron dense, and contained mitochondria, rough endoplasmic reticulum, numerous smooth membrane vesicles and one or two electron-dense granules (Fig. 3b). These cells also possessed some rough endoplasmic reticulum adjacent to the plasma membrane, an association reported for other systems involved in cell wall synthesis (Chrispeels, 1976). At low magnification, the membrane around these cells appeared more electron dense than that around the amoebae and there was some evidence of extrusion of material at the cell surface (Fig. 3b). At higher magnification these cells showed a thin electron- dense layer that in places was separated from the cell membrane, but there was no evidence of a distinct cell wall (Fig. 3c). In the samples fixed in the presence of Triton, the majority of cells were either dense and rounded or clearly lysed. The rounded cells were identical in ultrastructure to those illustrated in Fig. 3 (b). No walled cells were seen in preparations made by either of these methods.

Correlation of cell types with TRC induced by mannitol treatment. When thick sections of the preparations fixed in mannitol medium after $17 \mathrm{~h}$ treatment were examined by LM, the amoeboid and dense, rounded cell types described above could be distinguished (Fig. 3d). In thick sections of the sample fixed in the presence of Triton (Fig. 3e), most of the cells that were not dense and rounded had apparently been lysed by the Triton treatment prior to fixation (Table 2a). No walled cells were seen in preparations fixed by either method, and it seemed likely that the dense, rounded cells $(39.6 \%)$ corresponded with the TRC $(52.1 \%)$ detected in the Triton test. When cells that could not be clearly classified were excluded, the ratio of round to lysed cells was not significantly different at the $1 \%$ level from the ratio of unstained to stained cells counted in the Triton test (Table 2a).

Our results suggested that the TRC present after $17 \mathrm{~h}$ mannitol treatment were dense, rounded cells without walls. These cells resembled the 'young cysts' observed by Haars et al. (1979) in cultures of $P$. polycephalum amoebae after $24 \mathrm{~h}$ mannitol treatment. A similar cell resulting from mannitol treatment of a liquid culture is shown in an electron micrograph published by Williams \& Lafontaine (1984); this cell is described as a 'mature cyst', although it also lacks a clear cell wall.

Reversion of mannitol-induced TRC. When samples of amoebae (sub 31) that had been in mannitol medium for up to $24 \mathrm{~h}$ were resuspended in SDM, the majority of TRC apparently reverted to a Triton-sensitive state within a few minutes, and Triton tests in SDM detected less than $1 \%$ TRC (Table 3 ). Such rapid reversion had not been described previously, although Haars et al. (1979) reported reversion within $30 \mathrm{~min}$. Total cell number decreased after $24 \mathrm{~h}$ in mannitol medium; the number of TRC also decreased, possibly due to cell clumping. After $40 \mathrm{~h}$ in mannitol medium, however, an increase was detected in the percentage of TRC that did not revert when resuspended in SDM; a plateau was reached at about $47 \mathrm{~h}$ (Table 3 ). The results suggested that rapid reversion was a characteristic of cells without walls, and that the non-reverting cells might represent walled cells formed after long incubation in mannitol.

Observations on cells treated for $\mathbf{4 8} \mathrm{h}$ in mannitol medium. Samples were prepared for TEM after incubation of amoebae (sub 32) in mannitol medium for $48 \mathrm{~h}$. The suspension contained $50.0 \%$ TRC and a sample resuspended in SDM contained $2 \cdot 2 \%$ TRC. The cell suspension for TEM was fixed after addition of Triton (final concentration $0.025 \%$ ). Three cell types were 


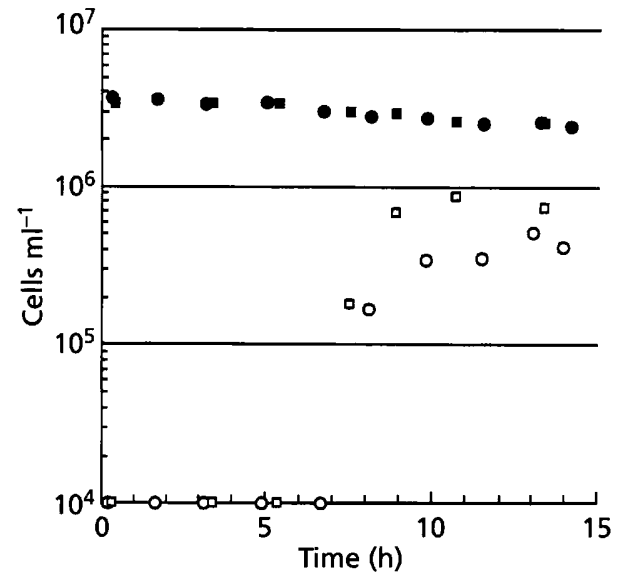

Fig. 2. Kinetics of TRC formation by amoebae resuspended in mannitol medium at time 0 . Experiment 1: $\mathbf{\square}$, total cells; $\square$, TRC. Experiment 2: 0 , total cells; $O$, TRC. All cell densities were calculated from counts on Triton-tested samples (mean for four cultures at each time-point). In samples before $7 \mathrm{~h}$, there were



detected: walled cells; dense, rounded cells without walls; and cells which had apparently been lysed (Fig. 3f). The walled cells resembled those seen in the preparations made from cultures on FKB. The other cell types were similar in appearance to those fixed in the presence of Triton after $17 \mathrm{~h}$ in mannitol medium.

Frequencies of cell types were estimated by counts of thick sections examined by LM. There were no significant differences between frequencies in upper and lower pellets. In the pooled data (Table $2 \mathrm{~b}$ ), the frequency of cells not lysed by Triton treatment, including those with walls, was $43.6 \%$ and the frequency of walled cells $0 \cdot 9 \%$. The results suggested that the cells not lysed by Triton might correspond to those defined as TRC by the Triton test in mannitol $(50.0 \%)$ and that the walled cells might correspond to the TRC which did not revert when resuspended in SDM $(2 \cdot 2 \%)$. To test this hypothesis, the expected numbers of walled, round and lysed cells in the sample (total 559, omitting those not clearly classified) were calculated on the basis of the Triton tests and compared with the numbers observed (Table 2b). The difference between expected and observed numbers was not significantly different at the $1 \%$ level. It was concluded that the majority of TRC present after $48 \mathrm{~h}$ mannitol treatment were not walled cells but that a few walled cells had been formed by this time and that only these remained Triton-resistant when suspended in growth medium.

\section{Formation of TRC on agar medium without bacteria}

Amoebae from liquid cultures (sub 31) approaching stationary phase at a density of $1.5 \times 10^{7}$ cells $\mathrm{ml}^{-1}$ were spread on three different agar media, without bacteria, incubated and assayed (Fig. 4). After $68 \mathrm{~h}$ on SDM agar the total cell number had doubled, but very few TRC were present (Fig. 4a). On the other media, there was little change in total cell number and \% TRC had reached a maximum by $68 \mathrm{~h}$; at this time, there were $12.5 \%$ TRC on DSDM (Fig. $4 \mathrm{~b}$ ) and $61.5 \%$ TRC on DSPB (Fig. 4c). Since SDM and DSDM differed only in concentration, and DSPB differed from DSDM only in $\mathrm{pH}$, the results suggested that both nutrient deprivation and increased $\mathrm{pH}$ were causal factors in TRC formation.

Samples prepared for ultrastructural examination. Amoebae from liquid cultures (sub 32) were inoculated on DSPB agar and incubated for $4 \mathrm{~d}$. Cells harvested in SDM contained $50.0 \%$ TRC; they were fixed with glutaraldehyde for TEM examination. In thick sections (Fig. $3 \mathrm{~g}$ ), the four cell types distinguished were similar to those seen on DSPB with FKB: walled cells; rounded, dense cells without walls; amoebae; and cells that were dead or dying. The walled cells formed under these conditions were identical to those seen on FKB (compare Fig. 3h with Fig. 1g). Cell counts on photographs of thick sections showed no significant difference in the frequencies of the cell types between lower and upper pellets (Table 4). Although the frequency of walled cells in the pooled data $(41.1 \%$ ) was lower than the $50.0 \%$ TRC detected, the difference was not statistically significant (Table 4), suggesting that the TRC were walled cysts. The results were also consistent with the hypothesis that the round, dense cells without walls, in addition to the walled cells, were Triton resistant (Table 4). The cell counts confirmed that the majority of TRC formed in axenic conditions on agar were walled cysts identical in appearance with cysts formed on bacterial lawns.

Survival after Triton treatment and reversion of TRC formed on axenic agar. LU352 (sub 34) amoebae, which had reached $2 \times 10^{7}$ per $\mathrm{ml}$ in liquid culture, were inoculated on DSPB agar at $4 \times 10^{6}$ cells per plate and incubated for $5 \mathrm{~d}$ to obtain TRC. Two plates were harvested in SDM and two in water; all suspensions were treated with Triton to kill the cells that had not formed TRC. The cells were then spun down and resuspended in either SDM or water for a further period to allow reversion of surviving TRC. Triton tests after $1 \mathrm{~h}$ indicated that only $8 \%$ of cells in the SDM suspensions were active, Tritonsensitive amoebae, in contrast with $76 \%$ in the suspensions in water. Thus, TRC formed on axenic agar differed from mannitol-induced TRC and resembled cysts formed on bacteria in reverting only slowly in SDM. All suspensions were finally resuspended in SDM and gave rise to active cultures of amoebae after several days incubation; thus TRC formed on axenic agar survived Triton treatment in water or SDM.

Subsequent experiments showed that the axenic cysts survived freezing by the methods used for cysts formed on bacterial lawns (Dee, 1986), and storage for at least six weeks at $-80^{\circ} \mathrm{C}$. Long-term survival is under investigation. If successful, this will avoid the need to use amoebae cultured on bacterial lawns to establish fresh axenic cultures, a procedure which is timeconsuming and inefficient because of the slow growth 

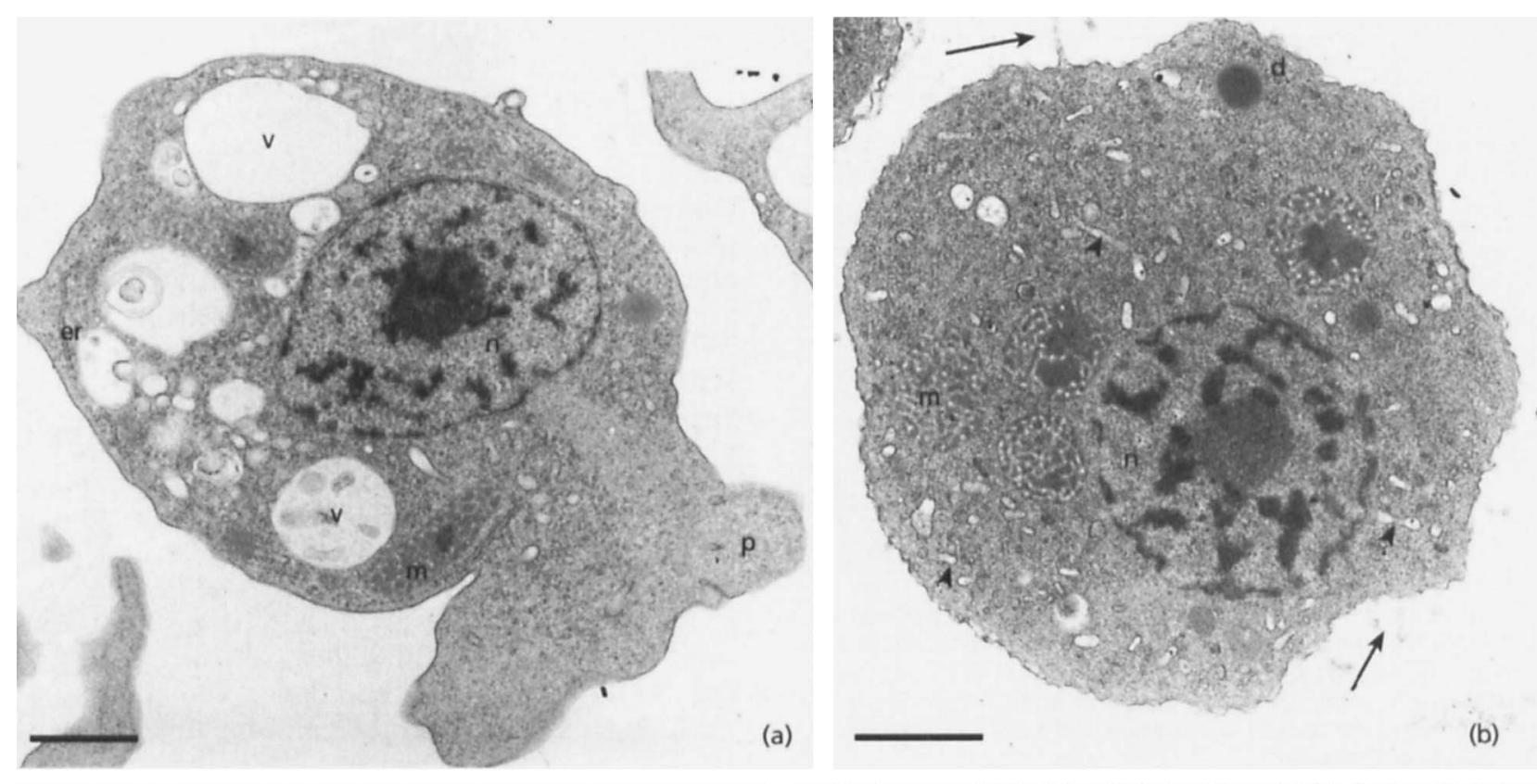

a)

(b)
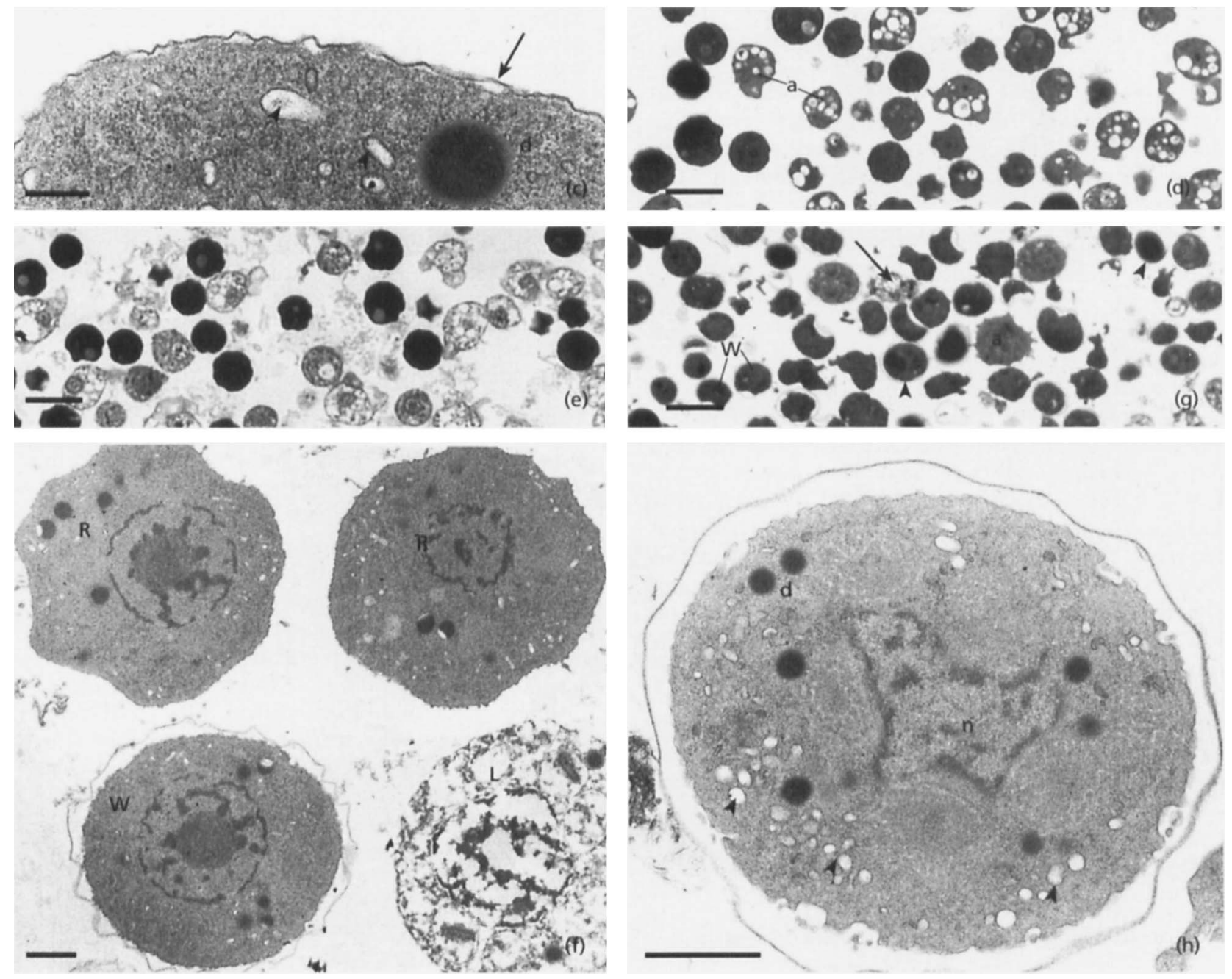

Fig. 3. For legend see facing page. 
Table 2. Cell types in populations incubated in mannitol medium for $17 \mathrm{~h}$ or $48 \mathrm{~h}$ and then fixed in mannitol + Triton

\begin{tabular}{|lcccrc|}
\hline \multirow{2}{*}{$\begin{array}{l}\text { Time in } \\
\text { mannitol } \\
\text { medium }\end{array}$} & \multicolumn{3}{c}{ Cell types seen in LM counts of thick sections: } & \\
\cline { 2 - 5 } & Walled & Round & Lysed & Not clear & \multirow{2}{*}{ Total } \\
\hline (a) $17 \mathrm{~h}^{*}$ & $0(<0 \cdot 2 \%)$ & $159(39 \cdot 6 \%)$ & $233(58 \cdot 1 \%)$ & $9(2 \cdot 2 \%)$ & 401 \\
(b) $48 \mathrm{~h} \dagger$ & $5(0 \cdot 9 \%)$ & $243(42 \cdot 7 \%)$ & $311(54 \cdot 6 \%)$ & $10(1 \cdot 7 \%)$ & 569 \\
\hline
\end{tabular}

*Counts shown for lower pellet only; upper pellet not tested. The ratio of round cells:lysed cells $(159: 233)$ was not significantly different at the $1 \%$ level from the ratio of unstained cells: stained cells (79:74) in Triton tests prior to fixation $\left(\chi^{2}=5 \cdot 5 ; n=1 ; P>0.01\right)$.

† Counts for upper and lower pellets not significantly different; total counts shown. Observed numbers of walled, round and lysed cells were compared with numbers expected on the basis of Triton tests in mannitol medium and in SDM (see text); difference not significant at the $1 \%$ level $\left(\chi^{2}=9 \cdot 3 ; n=1\right.$; $P<0.01)$.

Table 3. Frequency of TRC in mannitol medium and after re-suspension in SDM

Cells which had been incubated in mannitol medium for the times shown were sampled for Triton tests; cell samples were also resuspended in SDM and immediately sampled for Triton tests.

\begin{tabular}{|c|c|c|c|c|}
\hline \multirow[t]{2}{*}{ Time (h) } & \multicolumn{2}{|c|}{ Cells $\mathrm{ml}^{-1}$ in mannitol medium } & \multicolumn{2}{|c|}{ Cells $\mathrm{ml}^{-1}$ in SDM } \\
\hline & Total & TRC & Total & TRC \\
\hline $18 \cdot 5$ & $4.0 \times 10^{6}$ & $2.8 \times 10^{6}(70.0 \%)$ & $3.2 \times 10^{6}$ & $1 \times 10^{4}(0 \cdot 3 \%)$ \\
\hline $24 \cdot 5$ & $3.0 \times 10^{6}$ & $2.2 \times 10^{6}(73.3 \%)$ & $2.5 \times 10^{6}$ & $1 \times 10^{4}(0 \cdot 4 \%)$ \\
\hline $42 \cdot 0$ & $3 \cdot 8 \times 10^{6}$ & $2.2 \times 10^{6}(57.9 \%)$ & $2.6 \times 10^{6}$ & $2.0 \times 10^{5}(7.7 \%)$ \\
\hline $47 \cdot 0$ & $3.0 \times 10^{6}$ & $1.8 \times 10^{6}(60.0 \%)$ & $2 \cdot 3 \times 10^{6}$ & $3.0 \times 10^{5}(13.0 \%)$ \\
\hline $66 \cdot 5$ & $2 \cdot 8 \times 10^{6}$ & $1.5 \times 10^{6}(53.6 \%)$ & $1.8 \times 10^{6}$ & $1.7 \times 10^{5}(9.5 \%)$ \\
\hline $90 \cdot 0$ & $2 \cdot 2 \times 10^{6}$ & $1.2 \times 10^{6}(54.5 \%)$ & $1.6 \times 10^{6}$ & $2 \cdot 3 \times 10^{5}(14.4 \%)$ \\
\hline
\end{tabular}

rates obtained during early subcultures in liquid medium.

\section{CONCLUSIONS}

\section{Detergent resistance is not a reliable test for encystment}

When Triton tests were carried out in SDM, the majority of detergent-resistant cells detected were walled cysts. Triton tests in the presence of mannitol, however, were clearly not reliable for the detection of walled cysts; the majority of TRC detected corresponded to dense rounded cells without walls. The ability of these mannitol-induced TRC to survive Triton treatment in the presence of mannitol is attributed to a temporary structural change induced by the increase in osmotic pressure; when mannitol is removed, the cells rapidly revert to a Triton-sensitive state. In contrast, walled cysts have a more stable structure and remain Tritonresistant for many hours in SDM. In all cell suspensions examined, from mannitol treatment and from agar, there was a good correlation between the frequency of TRC that reverted slowly in SDM and the frequency of walled cells.

Fig. 3. P. polycephalum amoebae, walled and non-walled cells. TEM micrographs unless stated otherwise (d, electrondense granule; er, rough endoplasmic reticulum; $m$, mitochondria; $n$, nucleus; $p$, pseudopodium; $v$, vacuole). (a) An amoeba fixed in mannitol medium. Bar, $1 \mu \mathrm{m}$. (b) A rounded cell fixed after $17 \mathrm{~h}$ in mannitol medium. There are numerous smooth membrane vesicles (arrowheads) and electron-dense granules (labelled ' $d$ ') in the cytoplasm and indications of extrusion of material from the cell surface (arrows). Bar, $1 \mu \mathrm{m}$. (c) A rounded cell fixed after $17 \mathrm{~h}$ in mannitol medium showing an electron-dense layer (arrow) adjacent to the cell membrane (arrowheads indicate smooth membrane vesicles). Bar, $0.25 \mu \mathrm{m}$. (d) Light micrograph of cells fixed after $17 \mathrm{~h}$ in mannitol medium showing amoebae (labelled ' $a$ ') with conspicuous vacuoles and dense rounded cells. Bar, $10 \mu \mathrm{m}$. (e) Light micrograph of cells fixed in the presence of Triton after $17 \mathrm{~h}$ treatment in mannitol medium. Only the dense rounded cells remain unlysed. Bar, $10 \mu \mathrm{m}$. (f) Cells treated for $48 \mathrm{~h}$ in mannitol medium and fixed in the presence of Triton. Three cell types were present: walled cells (W), rounded cells without walls (R), and lysed cells (L). Bar, $1 \mu \mathrm{m}$. (g) Light micrograph of cells cultured for $4 \mathrm{~d}$ on DSPB agar without bacteria and harvested in SDM. Four cell types were seen: walled cells $(W)$, rounded cells without walls (arrowheads), amoebae (labelled ' $a$ '), and dead or dying cells (arrow). Bar, $10 \mu \mathrm{m}$. (h) A walled cell cultured for $4 \mathrm{~d}$ on DSPB agar and harvested in SDM (arrowheads indicate smooth membrane vesicles). Bar, $1 \mu \mathrm{m}$. 


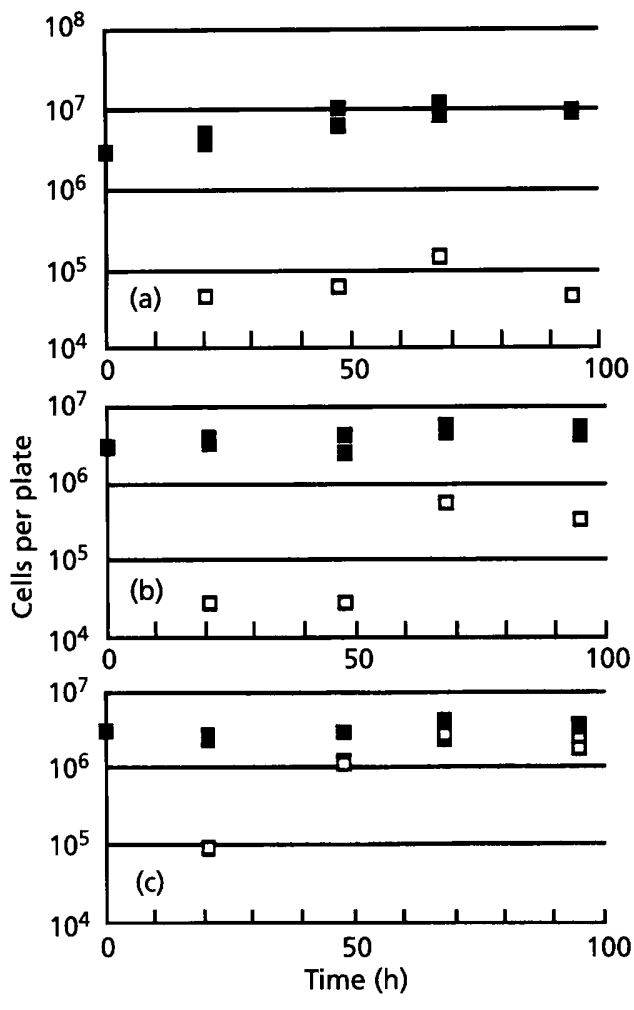

Fig. 4. Growth and TRC formation of amoebae on axenic agar media without bacteria. Amoebae from liquid SDM cultures were inoculated on the following media at $3.0 \times 10^{6}$ cells per plate: (a) SDM agar; (b) DSDM agar (pH 4.6); (c) DSPB agar (pH 6.8). $\square$, Total cells; results shown for two plates washed off at each time-point; cell number calculated from mean count for wash-off suspension and Triton-tested sample. $\square$, TRC; results for two plates shown where TRC $>10^{6}$ per plate; mean for 2 plates shown where TRC $<10^{6}$ per plate.

Thus, although Triton tests provide a quick and convenient method for detecting cysts among cells suspended in media such as SDM, their use in media of high osmotic pressure can be misleading. Detergent resistance was the criterion for encystment used by Binette et al. (1988) when they attempted to identify encystment-specific genes in a cDNA library constructed from TRC induced by glucose. Although they identified two mRNAs specific to the TRC, our observations suggest that these cells may not have been true cysts. For studies such as analysis of gene expression, detergent resistance should not be the sole criterion for encystment.

\section{There is no evidence that mannitol induces encystment}

Although approximately $40 \%$ of amoebae respond to mannitol treatment within a few hours by becoming Triton resistant, our results provided no support for the assumption by previous authors that these cells are 'young cysts' (Haars et al., 1979). The majority remain unstable and revert immediately in SDM. Only a small proportion of cells $(<1 \%)$ became walled after $48 \mathrm{~h}$ treatment and no further increase in the frequency of non-reverting TRC was observed after $96 \mathrm{~h}$. We found no evidence that mannitol treatment induced the formation of walled cysts.

\section{Encystment can be induced in axenic conditions on agar}

Efficient encystment in axenic conditions was induced by transferring amoebae from liquid cultures to nonnutrient axenic agar. Unlike mannitol-induced TRC, these cysts appeared identical in structure with those formed on bacterial lawns and reverted slowly in SDM. They survived freezing and were used to establish axenic cultures of amoebae.

Since total cell number remained constant during cyst formation, the results do not support the conclusion of Fry \& Matthews (1987) that cell division is necessary for amoebal encystment. Our results indicate that a solid substratum as well as nutrient deprivation are required to induce encystment in $P$. polycephalum amoebae. Although a few cysts are formed after long incubation in liquid SDM or mannitol medium, even these may have attached to the walls of the culture vessel or to one another in clumps. Previous results suggested that

Table 4. Cell types in populations incubated on DSPB agar without bacteria

\begin{tabular}{|llllll|}
\hline & \multicolumn{3}{l}{ Cell types seen in LM counts of thick sections: } & \\
\cline { 2 - 5 } & Walled $(\boldsymbol{a})$ & Round $(\boldsymbol{b})$ & Amoeboid $(\boldsymbol{c})$ & Dying $(\boldsymbol{d})$ & Total \\
\hline Lower pellet* & 99 & 35 & 88 & 17 & 239 \\
Upper pellet* & 110 & 48 & 83 & 29 & 270 \\
Total $\dagger$ & $209(41 \cdot 1 \%)$ & $83(16.3 \%)$ & $171(33.6 \%)$ & $46(9.0 \%)$ & 509 \\
\hline
\end{tabular}

* Counts for $(a)-(d)$ not significantly different between lower and upper pellets $\left(\chi^{2}=4 \cdot 0 ; n=3 ; P>\right.$ $0 \cdot 05)$.

† Ratio of unstained cells : stained cells $(45: 44)$ in Triton tests prior to fixation did not differ significantly from ratio of $a:(b+c+d)(209: 300)$ nor from ratio of $(a+b):(c+d)(292: 217) ;\left(\chi^{2}=2 \cdot 8\right.$ and 1.9 respectively; $n=1 ; P>0 \cdot 05)$. 
plasmodium development of $P$. polycephalum amoebae also requires a solid substratum (Dee et al., 1989, and unpublished data).

\section{ACKNOWLEDGEMENTS}

We are grateful to Dr Roger Anderson and Dr Juliet Bailey for many stimulating discussions during the course of the work and for helpful comments on the manuscript.

\section{REFERENCES}

Aldrich, H. C. \& Blackwell, M. (1976). Resistant structures in the Myxomycetes. In The Fungal Spore, pp. 414-462. Edited by D. J. Weber \& W. M. Hess. New York: John Wiley.

Anderson, R. W., Gray, A., Hutchins, G. \& Price, J. (1983). Preservation of Physarum polycephalum amoebae with anhydrous silica gel. Physarum Newsl 15, 3.

Bailey, J., Benard, M. \& Burland, T. (1994). A luciferase expression system for Physarum that facilitates analysis of regulatory elements. Curr Genet 26, 126-131.

Binette, F., Pallotta, D. \& Lemieux, G. (1988). Different developmental programs for amoebal and plasmodial encystment in Physarum polycephalum. Curr Genet 13, 151-157.

Burland, T. G., Bailey, J., Pallotta, D. \& Dove, W. F. (1993). Stable, selective, integrative DNA transformation in Physarum. Gene 132, 207-212.

Chet, I. \& Rusch, H. P. (1969). Induction of spherule formation in Physarum polycephalum by polyols. J Bacteriol 100, 673-678.

Chrispeels, M. J. (1976). Biosynthesis, intracellular transport, and secretion of extracellular macromolecules. Annu Rev Plant Physiol 27, 19-38.

Dee, J. (1986). The culture of Physarum amoebae in axenic media. In The Molecular Biology of Physarum polycephalum, pp. 253-269. Edited by W. F. Dove, J. Dee, S. Hatano, F. B. Haugli \& K.-E. Wohlfarth-Bottermann. New York: Plenum Press.

Dee, J., Foxon, J. L. \& Anderson, R. W. (1989). Growth, development and genetic characteristics of Physarum polycephalum amoebae able to grow in liquid, axenic media. J Gen Microbiol $135,1567-1588$.

Fry, J. \& Matthews, H. R. (1987). Flow cytometry of the differentiation of Physarum polycephalum myxamoebae to cysts. Exp Cell Res 168, 173-181.

Gorman, J. A., Dove, W. F. \& Shaibe, E. (1977). Anisomycin sensitive mutants of Physarum polycephalum isolated by cyst selection. Mol Gen Genet 151, 253-259.

Haars, A., Zaar, K. \& Huttermann, A. (1979). Induction of synchronous differentiation (encystment) in Physarum polycephalum myxamoebae. Arch Microbiol 120, 105-112.

Henney, H. R. \& Chu, P. (1977). Chemical analyses of cell walls from microcysts and microsclerotia of Physarum flavicomum; comparison to slime coat from microplasmodia. Exp Mycol 1, 83-91.

Howard, F. L. (1931). The life history of Physarum polycephalum. Am J Bot 18, 116-133.

Madelin, M. F. (1990). Methods for studying the ecology and population dynamics of soil myxomycetes. Methods Microbiol 22, 405-416.

Raub, T. J. \& Aldrich, H. C. (1982). Sporangia, spherules and microcysts. In Cell Biology of Physarum and Didymium, vol. II, pp. 21-75. Edited by H. C. Aldrich \& J. W. Daniel. New York: Academic Press.

Rhea, R. P. (1966). Electron microscopic observations on the slime mould Physarum polycephalum with specific reference to fibrillar structures. J Ultrastruct Res 15, 349-379.

Turner, H. M. \& Johnson, J. (1975a). Transmission and scanning electron microscopy of changes associated with microcyst formation in the myxamoebae of Physarum polycephalum. Cytobios $12,95-107$.

Turner, H. M. \& Johnson, J. (1975b). A biochemical analysis of induction of microcyst formation in Physarum polycephalum myxamoebae by mannitol. Cytobios 13, 229-239.

Turner, H. M. \& Johnson, J. (1975C). Ultrastructural changes associated with induction of microcyst formation by mannitol in Physarum polycephalum amoebae. Cytobios 13, 241-250.

Williams, L. M. \& Lafontaine, J.-G. (1984). Ultrastructural changes in the myxamoebae of Physarum polycephalum in response to a microcyst-inducing concentration of mannitol. Can J Bot 62, 272-280.

Received 21 August 1996; revised 29 November 1996; accepted 17 December 1996. 